\title{
Irish Female Members of the European Parliament: Critical Actors for Women's Interests?
}

\section{Pauline Cullen}

\section{Maynooth University, National University of Ireland}

T istorically, the European Parliament (EP) is credited as an important 1 actor in improving the rights of women in Ireland (Murphy and O'Brennan 2014). ${ }^{1}$ Ireland's gender regime is conservative Catholicliberal with a familialist orientation, where levels of female representation in decision-making remain low, intimate citizenship is restricted, and women remain overrepresented in low-paid employment and unpaid care work (Devitt 2016). Lacking a power base in national political parties, Irish feminists and European Union (EU) officials, including members of the EP (MEPs), have worked to secure progress on gender equality issues such as equal pay legislation (Hobson 2003). This research explores whether, in the contemporary context, Irish female MEPs remain critical actors for women's interests at the EU level.

This work is timely, as 2014 marked the first time since Irish accession to the $\mathrm{EU}$ in 1973 that Irish female MEPs achieved majority status in their national representation. Irish women MEPs now hold 6 of 11 seats, whereas at the national level, Irish female MPs constitute $22.3 \%$ of the Irish Parliament. ${ }^{2}$ Acknowledging the insight of feminist institutionalist analysis that "the presence of women in parliaments and legislatures at whatever proportion, tipping point or critical mass - does not simply

\section{1. "Ireland" here refers to the Republic of Ireland.}

2. As of February 2016, the Parliament had $15.5 \%$ female representation. The increase is due in part to the introduction of candidate gender quota legislation for national elections in 2012. The legislation mandated a $50 \%$ reduction in state funding to political parties who failed to meet a $30 \%$ gender candidate quota; the quota will increase to $40 \%$ in 2019.

Published by Cambridge University Press 1743-923X/18 \$30.00 for The Women and Politics Research Section of the American Political Science Association.

(C) The Women and Politics Research Section of the American Political Science Association, 2018 doi:10.1017/S1743923X1800020X 
or automatically translate into substantive action on behalf of the unstable category 'women' and their contestable 'interests"' (Mackay 2008, 125), this research evaluates Irish female MEPs as political agents for women's interests.

Analysis of legislator agency and agenda-setting behavior for women at the national level (Erzeel 2015) and scholarship on critical actors (Childs and Krook 2009; Dahlerup 1988) and female political agency (Buckley and Galligan 2013) provides a framework for examining the factors that shape female political agency and acts for women. Erzeel (2015) explored legislators' attitudes and their access to resources and opportunities as determinants of their actions on behalf of women. She concluded that factors including feminist awareness, gender-related resources, and incentives received from the party political context support legislators' agency to pursue women's interests. Irish female politicians at the national level (Buckley and Galligan 2013) and MEPs operate in a context that may limit or enhance their political agency to serve as critical actors for women. This context includes the gendered nature of Irish political institutions, the local political culture, the gender regime, and the form of Europeanization articulated. Irish female MEPs also advance varying levels of gender awareness that is implicitly feminist or absent a feminist framework. Accordingly, the concept of gendered mobilization (Irvine, Lang, and Montoya, forthcoming) is used to offer a comprehensive and flexible assessment of legislators' advocacy for women's interests that incorporates the diversity of feminist and gendered interests that constitute the substantive representation of women (Celis et al. 2014).

This work contributes to gender and politics theorization of the factors that influence the capacity and intent of female politicians to act for women (Celis et al. 2014) and aims to broaden the theorization of how resources and opportunities shape female political agency to advance women's interests at the transnational level. It also adds to work on the $\mathrm{EP}$ as a context for the construction of women's interests and the pursuit of gender equality (Agustín 2012; Ahrens 2016). A better understanding of female political agency in the EP is relevant in the context of a decline in the EU's commitment to gender equality (Karamessini and Rubery 2013), an increased presence of right-wing politicians in the EP (Mushaben 2015), and the deleterious effect of austerity on gender equality in Irish society (Barry and Conroy 2014). Findings suggest that national political culture and party ideology are contextual factors that mediate female political agency for women's interests in the EP. Irish 
female MEPs do act for women in gendered forms of mobilization that follow broad EU frameworks that define women as mothers and workers. However, ideology and party political discipline, the pull toward local and national interests, and an absence of strong feminist agency work to diminish opportunities for female MEPs to act as critical actors and deliver critical acts on women's interests.

\section{METHODOLOGY}

Previous studies have employed large-scale survey and quantitative analyses of roll call voting behavior or gender gaps in political attitudes to explore patterns of female representation in the EP (Fortin-Rittberger and Rittberger 2014; McEvoy 2016). Female national delegations to the EP have also been studied, with a view toward understanding the discrepancies in women's rates of election between the national and EP levels in the context of adjudicating claims that the EP is a more woman-friendly context (Beauvallet and Michon 2008; Lühiste and Kenny 2016). This study differs in moving beyond the descriptive representation or physical presence of female national delegations to exploring, in small-case qualitative terms, the experiences and attitudes of female politicians. This method carries with it the contingencies of a small-sample, single-case approach in terms of limits on the explanatory range (Yin 2014). However, the aim here is to combine a broad contextualization with an in-depth account from strategically selected participants. The small sample size also limits the generalizability of the data. Therefore, the intent here is not to offer a comprehensive account of the complex factors that shape MEP influence and orientation; rather, it is to generate knowledge that can contribute validity in privileging the experiences and understandings of women from a specific national context in governance at the transnational level.

Many analyses of the EP rely on institutionalist or weakly social constructivist perspectives that underplay agency over structure (Bowler and McElroy 2015). Understanding whether women in political office are more likely to act in the interests of other women requires learning about their attitudes and their own assessments of their capacity to act on those preferences - in other words, their own assessments of their political role and agency (Domingo et al. 2015, 30). This research adopts a sociological and qualitative approach drawing on in-depth semistructured interview data with six sitting and past female MEPs. This 
represents half of all Irish women who have ever held an MEP position and includes representatives from all parties and independents. Interviews were conducted face to face with follow up telephone communication. ${ }^{3}$ Topics covered in the interviews include paths to political office; experiences in the national political context compared with the EP; evaluation of the working environment in the EP; membership on EP committees; working relationships and alliance structures' understanding of women's interests; feminist identification and gender equality; and attitudes toward and illustrations of their work at the EP level to advance women's interests (including addressing an issue considered to disadvantageous to women). Additional interview data from six civil society actors working on gendered interests and feminist advocacy in Ireland and at the EU level supplement the analysis. The later interviews explored the relationships between advocates for women's rights and EU processes and actors, including the EP and specifically female MEPs.

Document analysis of parliamentary portfolios, social media, and media communications was also conducted to explore how Irish female MEPs define and act on "women's interests." Document analysis focused on the official EP electronic profile of each participant, which contains records of speeches made and reports authored, including the responses of the participants to the reports of the EP's Committee on Women's Rights and Gender Equality (FEMM). Most research on the EP from a gender and politics perspective has focused on the activities of the FEMM committee (Ahrens 2016) or on feminist institutionalist assessments of EP party political groupings (Kantola and Agustín 2016). In contrast, this analysis looks at how one national representation of female MEPs engages on women's interests across their parliamentary service, committee membership, and extraparliamentary processes. I acknowledge that future research could elaborate on the findings presented here if additional interviews with male MEPs and in comparative terms from different member states were conducted.

I begin with an overview of debates within politics and gender scholarship on the concept of critical actors and the factors identified that facilitate or constrain representatives in acting for women. EU membership, and more specifically mobilization within the EP, has been important for progress on gender equality in Ireland. Therefore, I continue with a brief contextualizing overview of the influence of $\mathrm{EU}$

3. All interviews were conducted between March and November 2015 in face-to-face interviews in Dublin, Ireland, and telephone interviews from Brussels and Strasbourg. 
membership on Irish public policy, governance, state, and society, with a particular focus on gender equality. This section details how Irish political culture, the gendered nature of Irish political institutions and structures, and the Irish experience of Europeanization have shaped the conditions under which Irish MEPs operate.

Next, I detail assessments of gender representation and the EP as a context for female political agency, followed by a profile of Irish female MEPs. I then turn to an analysis of female MEPs' own assessments of the EP as a context for female politicians and for addressing women's interests. As part of this, I outline relations between Irish MEPs and gendered civil society groups. This allows for an analysis of the substantive issues that female MEPs pursue and the gender constructs or ideas and frameworks about gender and gender equality that they employ in advocating for women's interests. Finally, I conclude by assessing whether we can understand Irish female MEPs as critical actors for women's interests.

\section{THEORIZING FEMALE CRITICAL ACTORS IN THE EUROPEAN PARLIAMENT}

Dahlerup (1988) argued that an increasing presence of women in parliamentary settings, while important, does not explain impact; instead, it is necessary to consider what women legislators actually do in order to assess whether the presence of women translates into the representation of their interests. She concluded that critical acts for women's interests, rather than a critical mass, explain change. In addition to traditional concerns about achieving a "critical mass" of women, scholars have also argued for questioning how we define critical acts and who the "critical actors" are (Chaney 2012). As Erzeel $(2015,441)$ noted, "The impact of a 'politics of presence' is foremost conditional: the institutional and party political environment matters and so do the identities of the women involved."

Following this lead, this research sets aside questions about the relationship between the critical mass of women and the substantive representation of women's interests to explore in more detail who the women are (Chaney 2012) and, crucially, in what ways we can understand female politicians to be "critical actors," defined as "those who act individually or collectively to bring about women-friendly policy change" (Childs and Krook 2009, 127). Research has expanded and 
complicated ideas about the substantive representation of women in terms of who can be considered a critical actor and where critical acts occur (Celis and Erzeel 2015; Celis, Childs, and Kantola 2016). ${ }^{4}$ However, as Chaney $(2012,442)$ outlined, "The umbrella term 'critical actor' now encompasses a range of types of actor and actions concerned with advancing the substantive representation of women." In response, this work examines specific women in a national delegation in the EP to provide a grounded theoretical assessment of female political agency and its potential to generate critical acts for women. Notably, female political agency can work in ways that reinscribe gendered norms and practices or that support critical acts that challenge the gendered foundations of democratic politics, political institutions, and the state (Buckley and Galligan 2013, 341-42).

Critical actors must be attitudinally committed, enjoy political agency, and operate where they can access resources and seize opportunities to act on behalf of women. Rather than focus on the postfactual political outcomes or success of critical acts as a measure of a critical actor, this analysis is interested in the factors that may support a female politician's agency to act for women as a critical actor. Erzeel's (2015) quantitative analysis of legislators' (self-reported) behavior on behalf of women in 11 countries offers a model in her focus away from policy output and toward interest representation and, notably, representatives' agency. In her analysis, individual politicians' agency to influence party positions in advance of formal policy output is a site for understanding what factors influence their attitudinal commitment to address situations that are disadvantageous to women in society (Erzeel 2015, 442-44). Legislators' feminist awareness, contacts with women's organizations, membership on equality committees, and the incentives they receive from the party political context were all identified as important sources of agency for actions on behalf of women (Erzeel 2015, 457-58). In the analysis here, Erzeel's large-scale quantitative assessment is rescaled to explore in qualitative terms how attitudes, resources, and opportunities affect individual female politicians' agency in acting for women.

Attitudinal commitment to act for women is a fundamental aspect of how female politicians exercise their agency, and it is connected in important ways to gender consciousness and feminist awareness (Erzeel 2015). Understanding MEPs as critical actors, then, must include an

4. Debates have centered on how women's interests are best understood as socially constructed, politically contested, and empirically contingent. 
assessment of their level of gender awareness. Comparative analysis of claims making on women's interests has revealed a contradictory range of normative views held by women across the ideological spectrum that reinforce existing gender relations, seek to promote gender equality, or reflect some combination of the two (Celis at al. 2014, 163). The concept of gendered mobilization (Irvine, Lang, and Montoya, n.d.) is used here to access the pursuit of gendered interests, which are defined as nonfeminist claims for and about women's material interests and gender roles. This formulation cautions against measuring critical actions on women's interests against a feminist checklist (Celis at al. 2014). This also allows for an expansion of the idea of resources beyond connections to feminist groups to include organizations and interests that have a gendered dimension but work outside feminist frameworks.

Added here to Erzeel's (2015) account is a focus on the influence of national political culture, including electoral rules. Contextual factors include party political affiliation, the multilevel institutional context, and the domestic electoral system and rules that create incentives or disincentives to represent women as a distinct constituency. What constitutes a critical act can also be context specific, as what constitutes a gender equality claim differs across national arenas. For political representatives from national contexts with specific gender deficits, such as in the Irish context, strong feminist justice claims maybe required to deliver change on enduring and pervasive forms of gender inequality. Therefore, the gender regime is also included as a contextual factor. Critical actors must have power to enact change. Given this, the level of executive incorporation of Irish female MEPs into the committees and portfolios of the EP is also included. Key indicators of the presence of these factors include stated attitudes toward women's issues and gender equality, selfreported actions to support women, documented connections to women's organizations, and access to gender expertise, including membership on equality committees.

The following section outlines the influence of Irish political culture, the implications of EU accession for Irish women, and the contemporary gender regime, which is understood here as key aspects of the context shaping Irish female MEPs' political agency and capacity for critical action on women's interests. 


\section{IRELAND AND EU MEMBERSHIP: POLITICAL CULTURE AND GENDER EQUALITY}

Irish accession to the European Economic Community in 1973 was motivated by a modernization imperative, economic concerns relating to the United Kingdom's membership in 1972, and a strategy to support an ailing agricultural sector. Ireland was a net recipent of EU revenue, some of which contributed to progressive outcomes but, at the same time, alleviated the need for the state to develop a comprehensive revenue base for social expenditure and welfare. Therefore, after 40 years of EU membership, Irish public policy has remained liberal in orientation and is in fact consistent with more recent EU market imperatives, including a commitment to austerity (Murphy and O’Brennan 2014).

Irish public support for European integration is also highly contingent, with specific implications for those aiming to use Europe - and in this case, the EP - to push for gender equality. Ireland's initial rejection of both the Nice (2001) and Lisbon (2008) revisions to the EU treaties has been understood as a testament to the power of the Catholic Church and Euroskeptics to employ a version of morality politics to link national sovereignty and abortion with further European integration (Nelsen and Guth 2015). Recent European elections in Ireland were "second-order" elections, in which voter choice was mainly influenced by a backlash against austerity, manifested in attitudes toward the incumbent centerright and center-left coalition. EU issues gained little traction in the campaign, and opinions on the EU had minimal impact on party choice, suggesting that domestic politics remain key to understanding EP elections in Ireland (Quinlan and Okolikj 2016).

Other characteristics of the Irish political system complicate Irish female MEPs' political agency, incentivizing single-issue local-level activity over the pursuit of critical actions for women as a constituency. A system of multiconstituent proportional representation means that political candidates and incumbents must engage in permanent campaigns based on establishing and maintaining a reputation for service delivery at the local level (Buckley and Galligan 2013). Irish MEPs are strongly influenced by pressures of what they can bring back to their local constituents. This reinforces elements of populism and clientelism at both the national and EU levels and shapes decisions of MEPs as to what portfolios and committee work to pursue. Analysis of the social media profile of the Irish female MEPs illustrates a strong emphasis on 
highlighting their presence and actions in their local context and/or their sponsorship of national and local delegations to EP events (Cullen, forthcoming). In sum, the pull toward local issues and poor levels of public understanding of the $\mathrm{EU}$ combine to narrow the incentives for Irish female MEPs to privilege women's interests.

Nevertheless, the EU has been an important modernizing influence on gender equality in Ireland. The actions of feminist groups and individuals employing supranational lobbying have been essential in forcing the Irish state to comply with legislation and policy relating to equal pay and improvements in maternity leave and parental leave. Examples include the removal of a marriage bar for female public sector workers in 1973 and 1977 legislation against discrimination on the grounds of sex. An increase in women's labor market participation from $42 \%$ to $61 \%$ was an important outcome of EU funds that were used for education, training, and supports for working mothers and child care in disadvantaged communities. That said, the EU Directive on Equal Treatment in Social Security took 16 years and several visits to the European Court of Justice to implement in Ireland. The introduction of gender mainstreaming was also prompted by EU funding, but it is weakly embedded at best across institutions and policy-making contexts (McGauran 2005). Cumulatively, then, these developments have improved access to employment, deepened legal equality, extended primarily passive support to women's increased public representation, and increased funding for improvements in women's representation on corporate boards and in STEM (science, technology, engineering, and mathematics) professions.

Although divorce is now legalized, the Irish record on intimate citizenship still compares poorly with most other member states. While the European Court of Human Rights has been an important context for loosening the restrictive abortion regime, abortion remains highly restricted. ${ }^{5}$ Irish women have the highest fertility rate in the $\mathrm{EU}$, but there is limited statutory paternity leave, no statutory entitlement to flexible working hours, and limited state support for child care. All of this combines to create a patriarchal dividend gained from restrictive

5. High-profile maternal mortalities linked to legal restrictions in medical decision-making led the Irish government to establish in 2016 a forum of randomly chosen citizens to hear testimony on the issue of abortion. This Citizen Assembly recommended legislative and constitutional reforms to the government in May 2017, which, if enacted, would amount to safe, legal abortion in Ireland. In late 2017, a parliamentary committee made similar recommendations, and in March 2018, the Irish government published wording for a referendum on the constitutional ban to be held in May 2018. 
reproductive rights, high-cost child care, and unrecognized care work (Buckley and Galligan 2013).

Buckley and Galligan (2013) outlined how male-gendered institutional norms in legislatures and parties in Ireland, in addition to a reluctance to recognize women as a political grouping and the invisibility of women's interests and perspectives, have worked to stifle gender balance in political office. Despite the introduction in 2012 of candidate gender quota legislation for national elections in Ireland (enacted in the 2016 general elections), the Irish Parliament ranks 80th in the world for women's representation. Until the enactment of the gender quota, ${ }^{6}$ Irish political parties had made meager progress on gender representation, resorting to equality rhetoric and equality promotion rather than equality guarantees, as illustrated by a rise in female MPs from 4.1\% in 1977 and to $15.5 \%$ in 2015 (Buckley 2013). ${ }^{7}$ Analysis confirms little support among Irish political parties for a woman-oriented policy platform (Buckley, Galligan, and McGing 2016). The legacy of this was most evident in 2017 in the ruling center-right party's appointment of a new government cabinet comprising of 34 ministers with a mere 7 female members.

Resources in the form of gender expertise and connections to women's organizations are also considered important factors in supporting a politician's capacity and attitudinal commitment to pursue women's interests. Equality infrastructure and women's organizations have fared poorly in the context of austerity, with a dismantling or mainstreaming of specific gender equality supports and services and a reduction in support for community organizations supporting women's interests. The overall effect is a weakening of capacity for feminist mobilization as the state has offloaded service provision to women's organizations and tied funding to conditionalities that have suppressed advocacy (Cullen and Murphy 2016).

Such significant deficits in gender representation and female political agency in the Irish party political environment suggest a lack of incentives and opportunities for female politicians to actively pursue women's interests. A resource-poor women's movement and the absence of a dedicated women's policy agency also undermines political representatives' access to gender expertise. However, it also suggests a context in which there exist areas in which critical acts may be required

6. Although it was not enacted until 2016, the gender quota legislation had preemptory effects on the 2014 local and EP elections in Ireland as parties prepared to meet the quota requirement.

7. The introduction of candidate gender quotas in Ireland is explained in part by demands for institutional change and political reform following the 2008 economic crash. 
to secure progress on women's issues. Irish female MEPs operate in a multilevel context. If domestic opportunities and incentives for mobilization on women's interests are weak, does the EU, and more specifically the EP, provide a favorable context for to Irish female MEPs to act for women's interests?

\section{THE EUROPEAN PARLIAMENT, GENDER REPRESENTATION, AND EQUALITY}

Gender equality as an issue at the EU level has been downgraded from a context in which women were treated as a separate category and afforded rights through equal treatment legislation to one in which diversity and antidiscrimination models have subordinated gender and equality to market norms (Jacquot 2015, 18-19, 177). ${ }^{8}$ While EU legislative commitments to gender equality have declined, the EP remains an important context for the representation of women, rising slightly from 35\% female MEPs in 2009 to 37\% in 2014, much higher than in most national parliaments of member states (Fortin-Rittberger and Rittberger 2014). Mushaben and Abels (2015) argued that it is this critical mass of women that allowed gender-friendly MEPs to advance important gender equality initiatives, generate data, and build coalitions to block legislation and the appointment of senior EU actors considered detrimental to gender equality. The current gender composition of Irish MEPs is five male and six female representatives, marking an increase of 29.5\% from the previous term, when 10 male and 5 female MEPs were elected. This is the first time since entry into the European Economic Community in 1973 that female MEPs have outnumbered male MEPs (see Table 1). ${ }^{9}$

However, the presence of women can be enhanced or neutralized as an opportunity for women's interests by broader institutional dynamics and the ideological makeup of a parliament. An institutional move toward intergovernmentalism in EU policy making and the rise of conservative political parties has left gender equality advocates in the EP with a

8. Factors contributing to this include EU enlargement to include socially conservative member states, a move toward a neoliberal economic program, and a decreased appetite on the member-state level for legally binding initiatives to advance gender equality.

9. European Parliament, Liaison Office in Ireland, "Irish MEPs, 1974-2014," http://www.europarl. ie/en/your_meps/irish_meps_since_1973.html (accessed April 20, 2018). 
number of stalled initiatives, including the advancement of quotas for corporate leadership posts, the expansion of maternity leave protections, and the mitigation of the gendered impact of austerity programs (Mushaben and Abels 2015).

Erzeel $(2015,444)$ noted how party political ideology, particularly in left-wing parties, can offer important incentives for representatives to act for women. MEPs and their national political parties are organized into party groups, and women are better represented in the left green party groups than in the conservative right ones (Kantola and Agustín 2016, 642). ${ }^{10}$ Aside from broad ideological formations, Kantola and Agustín (2016) analyzed the orientation of EP party political groups toward gender equality. They found that parties on the left debate gender equality by drawing on societal and structural explanations; however, the inclusion of parties on the right has marked an increase in individualist, liberal, numerical, and market-oriented ideas about gender equality (Kantola and Agustín 2016, 644). An increase in conservative views on gender relations is also a factor in strengthened division in the EP on issues such as sexual reproduction and health and rights (SRHR) (Agustín 2012; Kantola and Agustín 2015, 18-19). A consequence of this is that opposition to gender equality initiatives is often framed by right-wing MEPs as an issue of overreach of the $\mathrm{EU}$ into the private sphere of family life and the domestic sovereign competencies of the nation-state (Kantola and Agustín 2016, 646). In this way, gender equality has been used instrumentally by right-wing groups to argue against EU intervention, but also increasingly by those on the left who are unhappy with the EU's austerity policy (Kantola and Agustín 2016, 649). This shifting ideological balance in the EP, combined with a decline in political support for gender equality more broadly at the EU level, indicates a more complex context for critical acts for women than in the past.

Next, I profile individual female MEPs' power, perceptions, and reported actions on women's issues, revealing information on levels of attitudinal commitment and access to resources supportive of women's interests.

10. Female MEPs in the eight political groupings range from $21.9 \%$ in the European Conservatives and Reformists (ECR) to $52 \%$ in the European United Left-Nordic Green Left (GUE/NGL) (Abels 2015). 
Table 1. Irish MEPs

\begin{tabular}{lccc}
\hline EP Legislature & Irish MEP Delegation & Males & Females \\
\hline $1979-84$ & 22 & 20 & 2 \\
$1984-89$ & 17 & 15 & 2 \\
$1989-94$ & 17 & 15 & 2 \\
$1994-99$ & 15 & 12 & 3 \\
$1999-04$ & 15 & 10 & 5 \\
$2004-09$ & 13 & 8 & 3 \\
$2009-14$ & 12 & 9 & 3 \\
$2014-19$ & 11 & 5 & 6 \\
\hline
\end{tabular}

Source: http://www.europarl.europa.eu/portal/en.

\section{IRISH FEMALE MEPs}

Irish female MEPs reflect the major political party cleavages at the national level, where there are no large political parties representing either a hardleft or hard-right constituency. ${ }^{11}$ Among the six female MEPs, there are two representatives from the opposition center-left nationalist party, Sinn Féin (traditionally a Euroskeptical force) ${ }^{12}$; two members, including a vice president of the EP, from the incumbent center-right party, Fine Gael; and two independent representatives, one originating from a center-left and one from a center-right political affiliation. The two center-right MEPs belong to the EPP (Group of the European People's Party-Christian Democrats) center-right grouping; the center-right independent is a member of the ALDE (Alliance of Liberals and Democrats for Europe) grouping; the center-left independent MEP belongs to the S\&D (Group of the Progressive Alliance of Socialists and Democrats); and the two center-left MEPs are affiliated with the GUE/ NGL (Confederal Group of the European United Left/Nordic Green Left) (see Table 2). In biographical terms, Irish female MEPs are a combination of younger women acquiring political experience at the beginning of their careers and older women who have committed to the $\mathrm{EP}$ as a career for periods of 10 years or more. Four of the six women

11. There are smaller hard-left parties in Ireland, but they do not have representation in the EP.

12. Sinn Féin's position on EU membership has evolved, shifting from a strong form of Euroskepticism to a "critically engaged" position. The appointment of a new female leader, Mary Lou McDonald, in February 2018 coincided with a dramatic shift in the party's position on reproductive rights, with the party now formally supporting a repeal of restrictive abortion law in the May 2018 referendum. However, support for liberalization of abortion is not a universally held position within the party's membership. 
have served previously as elected officials, in Parliament, or at the local or mayoral level.

Executive incorporation is an additional aspect in assessing the capacity of female representatives to work as critical actors. Abels's $(2015,8)$ analysis of the gender representation of the EP emphasizes its quality as a "working parliament" in the central role played by committees, which are understood as central to the legislative process and where holding a formal leadership position or office affords influence (Busby 2013). Committee membership is also highly competitive, and membership on the most important committees is politicized (McElroy and Benoit 2012). Women chair 10 of the 22 committees, reflecting some progress on gender parity. This said, many of the portfolios held by women are "soft," and the most active and important committees and roles continue to be dominated by men (Abels 2015, 9). Notably, the two longestserving Irish female MEPs occupy the most powerful positions on the most important committees. One of the two longest-serving MEPs, Marian Harkin, is a coordinator for the ALDE group for the prestigious Employment and Social Affairs Committee. The other MEP with a long tenure, Mairead McGuinness, is a vice president of the EP who most recently ran for the nomination of the EPP party group for the presidency of the EP. She serves on the EP's influential Agriculture and Rural Development Committee and the Committee on the Environment, Public Health and Food Safety. A position on the Agriculture Committee, one of the most prominent areas of EU policy, is particularly important for Irish national interests, and McGuinness is noted as having significant influence in this committee. ${ }^{13}$

Interview data suggest that Irish female MEPs' expertise at the national level, local issues (especially for rural-constituency MEPs), and guidance from their political parties oriented their interest in seeking a specific committee membership. The other MEPs are full members of the environment, budget (another important committee), fisheries, and transport committees. Irish MEPs are located in a range of committees, with varying levels of influence. Only one Irish MEP, the independent center-left Nessa Childers, sits on the FEMM committee as a substitute member. Childers has been the most explicitly feminist MEP at the EU level and, as an independent, is unrestricted in ways that other female

13. Individual correspondence with former EP official from the Irish Permanent Representation, March 2017. 
MEPs are by the party whip system, which is strongly articulated in the Irish context. $^{14}$

Attitudinal commitment and access to resources are also key factors influencing representatives' political agency and their potential to be critical actors for women. Therefore, next I examine female MEPs' assessments of the EP as a context for female parliamentarians, their perceived role in pursuit of women's interests, their relationship to the FEMM committee, and their actions to support gendered civil society interests. In this assessment, I emphasize the gender ideologies and constructions employed.

\section{FROM NATIONAL POLITICAN TO MEP}

When asked about her experience in the national parliament compared with the EP, a first-time Irish female MEP noted, "There is such a difference going into meetings and not being the only woman in the room, also it is not as adversarial, it is more about consensus and you also realize there are a lot of women in very important positions." She also asserted that the EP offered a contrast to the national political scene, in that "there are certainly more females." Irish female MEPs were, in turn, careful to underplay gender deficits at national level. Instead, many of the women interviewed detailed their own leadership achievements, suggesting they had not personally been held back by gender bias while at the same time maintaining an awareness that it did exist.

When asked whether the greater number of women, in comparison with the national context, meant that the EP could deliver on gender equality issues, most female Irish MEPs interviewed agreed in broad terms. However, they differed in terms of whether they understood their work and the EP agenda as appropriately dedicated to this goal. A center-right female MEP suggested that "the EP is a place where we legislate for citizens, for men and women, not for women explicitly." A first-term center-left MEP asserted, "Of course the EP has been beneficial for gender equality in Ireland, but I think the way the EP works with co-decision, you need change to come from National Parliaments." The latter comment reflects a combination of an adherence to an antifederalist agenda, a diktat from her party, and an appreciation of the limits of current gender equality initiatives at the EU level. Overall, no

14. Lynn Boylan, Sinn Féin MEP, has evolved in her position to identify with a feminist perspective, illustrated by her campaigning on the national level for the repeal of restrictive abortion rights in 2018. 
Table 2. Irish Female MEPs

\begin{tabular}{|c|c|c|c|}
\hline & Political Party/EP Group & Term & EP Committee $(s)$ \\
\hline \multirow[t]{2}{*}{ Lynn Boylan } & Sinn Féin (center left/nationalist) & lst term & ENVI: Full member \\
\hline & European United Left/Nordic Green Left & $2014-29$ & $\begin{array}{l}\text { EMPL: Employment and Social Affairs, substitute } \\
\text { member }\end{array}$ \\
\hline \multirow[t]{2}{*}{ Liadh Ní Riada } & Sinn Féin (center left/nationalist) & lst term & BUDG: Budgets, full member \\
\hline & European United Left/Nordic Green Left & $2014-19$ & PECH: Fisheries, full member \\
\hline \multirow[t]{2}{*}{ Nessa Childers } & Independent & 2nd term & $\begin{array}{l}\text { CULT: Culture and Education, substitute member } \\
\text { ENVI: Full member }\end{array}$ \\
\hline & $\begin{array}{l}\text { Progressive Alliance of Socialists and } \\
\text { Democrats }\end{array}$ & $2009-19$ & $\begin{array}{l}\text { ECON: Substitute member } \\
\text { FEMM: Substitute member }\end{array}$ \\
\hline \multirow{2}{*}{$\begin{array}{l}\text { Mairead } \\
\quad \text { McGuinness }\end{array}$} & Fine Gael (center right) & 3 rd term & AGRI: Full member \\
\hline & $\begin{array}{l}\text { European People's Party } \\
\text { Vice president of the EP }\end{array}$ & $2004-19$ & ENVI: Substitute member \\
\hline Deirdre Clune & $\begin{array}{l}\text { Fine Gael (center right) } \\
\text { European People's Party }\end{array}$ & $\begin{array}{l}1 \text { st term } \\
2014-19\end{array}$ & TRAN: Transport and Tourism, full member \\
\hline \multirow[t]{2}{*}{ Marian Harkin } & Independent (center right) & 3 rd term & EMPL: Full member \\
\hline & $\begin{array}{l}\text { Alliance of Liberals and Democrats for } \\
\text { Europe }\end{array}$ & $2004-19$ & $\begin{array}{l}\text { ECON: Substitute member } \\
\text { PETI: Petitions, substitute member }\end{array}$ \\
\hline
\end{tabular}


Irish female MEP interviewed indicated a strong prioritization of women's interests in their role as parliamentarian.

Assessments of the EP as a work environment for female politicians also reveals the gender constructs and frameworks that Irish female MEPs draw on in making sense of their role and political agency and offer information into their respective level of gender awareness. When asked about the EP as a context for female politicians, a center-right MEP suggested that "I am not conscious of gender bias at all, it is just about the work." Asked about their party political grouping, it was suggested that "the EPP is full of strong women that can rise through the ranks." Another EPP member remarked that the group had made specific efforts to improve its gender balance, although she conceded that "ultra conservative" women within the group were an obstacle to certain gender equality initiatives.

For McGuinness, a center-right MEP, and a first vice president of the $\mathrm{EP}$, the fact that the EPP needed to address its low levels of female representation had presented her with an opportunity. In 2005, she secured the chair of a committee of inquiry, where as a first-term MEP, she developed her reputation and began her trajectory to her current position. The center-left MEPs also suggested that their left-leaning GUE/NGL political grouping was a context in which women could progress. Overall, female MEPs were reluctant to critique their party groups, a function perhaps of the relatively positive scenario compared with the national context and in line with other research (Kantola and Agustín 2016).

When asked to reflect on what female MEPs could do to advance their careers, the most experienced MEPs argued that women needed to make themselves "specifically visible and associated with a particular expertise or they would not progress." Advice to new female MEPs included "engage in committee work with a concrete piece of legislation and maintain your focus, communicate clearly, negotiate and avoid confrontational portfolios." This advice aligns with accounts from MEPs in other research that underline the necessity of a cooperative disposition, a reputation for hard work, and the capacity to avoid confrontation (Busby 2013). However, as research on gender representation in politics at the national level argues, female politicians face a double burden of conforming to the norms for MPs as well as male heteronormativity, which shapes patterns of social practice and access to power (Murray 2015).

The majority of female MEPs emphasized the responsibility that individual women had to seek opportunities to make themselves visible, prove their worth, and gain credibility. This focus on individual-level 
responses to a gendered institutional context and systemic gender inequality is illustrated by the support that Irish female MEPs from the right and left give to EU initiatives on women in decision-making. A center-left nationalist MEP remarked at an EP event on women in decision-making, "This is not about sexism. This is about inspiring and equipping women to succeed in politics." Such initiatives employ an economic argument for gender equality that reproduces individualized, depoliticized, and astructural frameworks that limit critical feminist analysis and argumentation around women's interests (Elomäki 2015). These assessments of the EP as a context for female politicians also indicate gender constructions of women as agents responsibilized for their own advancement in human capital terms, with an assessment of gender conflict and the gendering nature of institutions at the EU level largely absent (Kantola and Agustín 2016).

Given the preponderance of female politicians in the EP compared with the national context, participants were asked whether the EP was a place where women sought solidarity with other female politicians to work for women's interests. The response was clear: "Brussels is not about friendships it is more about business we don't get to engage on a purely female level." Another female MEP stated, "The EP is not about female friendship it is about the work and that is not necessarily about women's issues." Therefore, while younger MEPs acknowledged that more experienced female MEPs had offered advice, interview data confirm that women from the same national context did not claim a sense of sisterhood. Overall, most Irish female MEPs did not indicate a high level of attitudinal commitment to addressing women's interests; however, further assessment of levels of gender awareness and actions reveals a more complex picture.



The majority of Irish female MEPs supported an extension of EU legislation on maternity leave, a directive that has been blocked in the Council of the EU, and all have called for EU legislation to guarantee paid paternity leave in member states. However, party ideology is reflected in how female MEPs support women's interests. This is most clear when we look at how female Irish MEPs articulate positions around supports for working families. For example, a center-right female MEP evoked familial, human capital, the business case for gender 
equality, as well as demographic concerns on the blocked maternity leave directive, stating,

Employees being absent is a cost to business ... I think we are going to have to accept that it is just like rent, rates, holiday pay, and electricity costs. Populations need to be replaced and if women stop having children because their careers cannot bear a few months' absence, then the cost to us all would be much greater in the long run. Overall it is the cost to businesses of not retaining their female staff which is also at stake. ${ }^{15}$

Here gender constructs of women as workers and mothers are underlined, both predominant frames evident in EU frameworks (Pristed Nielsen and Agustín 2013).

Center-left MEPs are more likely to evoke issues of fairness and justice, broadening the issue to paternity leave and pushing back at more conservative frameworks on family life, evident in this statement:

Fathers too have a right to contribute to the earliest stages of development of their children across the Union. Paid paternity leave legislation is long overdue. It's interesting to see how conservative forces harp on about family values, yet show little enthusiasm for a modest improvement in the conditions of working people's family lives. ${ }^{16}$

This confirms to an extent how ideological cleavages shape how MEPs construct women's interests in the EP even if they broadly agree on similar issues (Pristed Nielsen and Agustín 2013). Erzeel (2015) argued that exposure to feminist attitudes and gender-related information from women's organizations are key resources in feminist awareness and, by extension, support for women's interests. One of the center-left MEPs admitted to being against gender quotas until she attended several events held by the Irish state feminist organization, the National Women's Council of Ireland (NWCI). Two of the center-right MEPs, with no ties to the NWCI, maintained their misgivings about the use of quotas.

A typical response from the center-right MEPs when asked whether they identified as feminist included, "No I don't use that label, I avoid blaming men, I am more interested in pushing for a balance and quality of life for

15. Deirdre Clune, European Parliament debate, May 20, 2015, http://www.europarl.europa.eu/ sides/getDoc.do?pubRef=-//EP//TEXT+CRE+20150520+ITEM-01 1-09+DOC+XML+V0//EN\& language $=$ en\&query $=$ INTERV\&detail $=3-450-000$ (accessed July 29, 2016).

16. European Parliament debate, March 10, 2015, http://www.europarl.europa.eu/sides/getDoc.do? pubRef=-//EP//TEXT+CRE+20150310+ITEM-012-10+DOC+XML+V0//EN\&language=en\& query=INTERV\&detail=2-298-414 (accessed June 22, 2016). 
men and women." Another stated, "Not a label I take on or reject it is just that I think it is better to normalize the issue of gender equality."

That said, Irish female MEPs have mobilized on women's interests in a diverse range of areas. Center-right female MEPs all advocated at the EU level for Irish civil society groups, working on gendered issues outside of feminist organizations. These include farming women, women in fisheries, and advocates for older people and carers for children and adults with a disability. ${ }^{17}$

As a vice president of the EP, the longest-serving Irish female MEP, Mairead McGuinness, has a long record of support for the rights of farming women ${ }^{18}$ and initiatives on child health and the deinstitutionalization of orphans and children with disabilities in Central and Eastern Europe. ${ }^{19}$ Liadh Ní Riada, a center-left first-term MEP, is a member of the committee on fisheries and has worked with the European Network of Women's Organizations in Fisheries and Aquaculture. focusing on women as workers in traditionally maledominated occupations. ${ }^{20}$ Other issues championed by Irish female MEPs include the rights of asylum-seeking women and children, the rights of Palestinian women, and development aid. Many of the issues championed by Irish female MEPs can be understood as "safe claims," where centrist and conservative women advance women's interests on issues including sex trafficking and women's development aid (Celis and Childs 2012, 221). Safe claims often involve gender constructs of women as victims from outside a national context, rather than a focus on domestic women's issues, which might require a disruption of the gender regime and/or substantial state intervention or cost (Childs and Krook 2009). A specific example of this is the adoption in the Irish context of EP and EU frameworks and legislation on the prohibition of sex work and its conflation with violence against women and human trafficking, predominantly understood as affecting non-Irish-born women. This relatively revenue-neutral initiative was supported by Irish female MEPs, although critics point to the problematic nature of the

17. Marian Harkin, "Carers," http://www.marianharkin.com/my-work/carers/\#.WPeWK9LyuUk (accessed April 19, 2017).

18. Mairead McGuinness, "Economic and Legal Status of Women Crucial to Arresting Rural Depopulation - EU Report," March 1, 2017, http://maireadmcguinness.ie/2017/03/01/economiclegal-status-women-crucial-arresting-rural-depopulation-eu-report/ (accessed April 11, 2017).

19. Mairead McGuinness, "Missing Children,” May 28, 2015, http://maireadmcguinness.ie/2015/05/ 28/missing-children/ (accessed March 19, 2017).

20. Sinn Féin, "Liadh Ní Riada Addresses International Fisheries Conference," September 8, 2016, http://www.sinnfein.ie/contents/41460 (accessed March 19, 2017). 
legal framework and continuing issues of significant underresourcing of services and supports for gender violence in the Irish context. In this sense, Irish female MEPs may give priority to women's issues, but they vary significantly in their assessment of whether government action is required to counter these problems.

It is important to note that female MEPs also pursue policy agendas without highlighting any gendered aspects. In negotiations on international trade agreements, including the Transatlantic Trade and Investment Partnership (TTIP), center-right and center-left female MEPs have focused on protections sought for Irish industry and agriculture rather than any gendered assessment. When asked whether her work on TTIP involved women's interests, one of the center-left MEPs reflected for a time on her focus on workers' rights, belatedly mentioning her efforts to secure social clauses, including those that address gender equality in public procurement processes. More recently, all of the Irish female MEPs have been involved in debates around the British exit from the EU, which has specific implications for Ireland. To date, none of their interventions has involved a gendered assessment.

Nonetheless, understandings and definitions of women's interests are not fixed but rather evolve over time and become constituted in political action (Celis et al. 2014). This is evident in the account given by a firsttime center-left MEP noting that although she had worked on food security at the national level, it was her time in the EP that had exposed her to the idea that this was an issue with specific implications for women. This realization had pushed her to think about food poverty in her work in the Environment, Public Health and Food Safety Committee in gendered terms. In her role on the Committee on Employment and Social Affairs, this same MEP has more recently contributed on the issue of poverty and gender. ${ }^{21}$

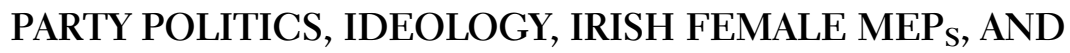 WOMEN'S INTERESTS}

Membership on a parliamentary equality committee is a strong indicator that representatives will act for women (Erzeel 2015). Equality committees are key contexts in which gender expertise is accessed. In the $\mathrm{EP}$, the FEMM committee is an important site for political struggles

21. Lynn Boylan, “Opinions - As Rapporteur,” European Parliament, http://www.europarl.europa. eu/meps/en/l24984/seeall.html?type=COMPARL (accessed June 12, 2016). 
over how women's interests are constructed and politicized at the EU level (Agustín 2012). It is recognized as the venue for critical acts for women (Mushaben and Abels 2015) and an inventive institutional actor that punches above its weight to secure gender equality outcomes (Ahrens 2016). Although its recommendations are nonbinding, its members, who are predominantly female, nonetheless bring substantial gender expertise to bear in other committees on which they serve (Mushaben and Abels 2015). However, Irish female MEPs have almost unilaterally declined membership on this committee.

Over the history of Irish EU membership, only three women have occupied either full or substitute membership on the women's rights committee. The most significant presence was a center-right politician and a long-serving MEP (1984-2004), Mary Banotti, who held either full or substitute membership between 1987 and 2002. Irish female MEPs have also played a retrograde role on gender equality issues in the past. For example, conservative MEP Dana Scallon agitated to refuse finding to the European Women's Lobby, an EU women's rights nongovernmental organization, and, in effect, to abolish the FEMM committee in 2000 (Agustín 2012). In the past 10 years, only one Irish female MEP has held membership, but as a substitute.

A more experienced female MEP, when asked about the FEMM committee, responded, "The FEMM committee is not relevant, as I am an engineer by training the transport committee is a better fit." Another remarked, "The FEMM committee does some good work but is has no legislative power, it is not in a position to push. There are other ways to secure gender equality, such as gender mainstreaming, gender proofing, or funding through the European Social Fund and European Regional Development Fund etc."

Center-right Irish female MEPs referenced gender mainstreaming as an initiative that displaced the need for specific committee membership on women's rights: "Gender mainstreaming means that in all my work there is a gender element." Analysis suggests that a reliance on gender mainstreaming processes in the work of EP committees has delivered weak or variable outcomes at best (Ahrens 2016).

In the view of another center-right female MEP, the FEMM committee had made some important mistakes, particularly on the long-stalled proposed revision of EU law on maternity leave. She commented, "Sometimes the Committee makes gender an issue in a way that inhibits legislation, they are not willing to compromise enough. Their position was inflexible and the result was that everybody's time was wasted." This 
MEP also stated, "I came to the EP to legislate to be where the influence is and that is not in the FEMM committee." The center-right Irish MEP who is also a vice president commented, "I have never attended a FEMM committee meeting, it is too left leaning, there are too many divisive voices and it is too adversarial." She continued, "When we look at the $\mathrm{EU}$, what are the major legislative priorities? Not on the FEMM committee. Where are Ireland's national interests? Not there." In her view, committees that are "womanized" are marginal; instead, women should be more visible in other contexts, such as agriculture.

Aside from these characterizations of the FEMM committee as irrelevant or radical, it is the issue of SRHR and the domestic political parties' line on abortion that explains Irish female MEPs' avoidance of this committee. Notably, SRHR remains a divisive issue in Ireland, avoided in local political contexts and tightly controlled by parties. As a center-left female MEP stated, "Political parties do not suggest to their MEPs to become members of the FEMM committee in part because of the issue of abortion." Asked to expand further, she explained that the issue of abortion was tied to federalist concerns, and until it was dealt with at home, no MEPs were encouraged to sit on the committee. She elaborated on this with reference to her rejection of the 2014 FEMM annual report on gender equality, which included a reference to abortion. She explained, "It is very frustrating when you cannot vote in favor of something like that, it is a pity that abortion was in there, as it would have gotten much broader support because there are so many other really important things in that report." When probed further, she admitted that she was personally pro-choice but that she had to comply with her party's diktat. Another center-right female MEP remarked, "High profile issues such as reproductive rights maybe feminist issues but are they are really what concerns women in the everyday life, such as caring for older parents, disabled children or working for low pay?" The EP record shows that only one female MEP, the independent Nessa Childers, voted for the 2014 report.

When asked about the work of the FEMM committee on SRHR, a center-right MEP commented, "I am pro-life, that is on the record, but also in this context subsidiarity is the reality. This insistence on trying to federalize the issue of abortion is futile." Positioning on issues of gender equality in instrumental ways aimed at reducing EU influence has increased in the EP, a strategy employed particularly by Euroskeptical rightwing and left-wing political interests (Kantola and Agustín 2016, 679). In this context, national party ideology and discipline trump individual views 
on women's interests. Antifederalism of the left-wing parties, coupled with the social conservatism of the center-right female politicians, restricts their political agency and capacity for critical action on this issue.

Connections to women's organizations are also seen as important predictors of attitudinal commitment to women's issues (Celis and Erzeel 2015) and a source of gender expertise to support critical acts (Dahlerup 1988). Connections between MEPs and domestic civil society groups are visible when MEPs sponsor their attendance at parliamentary hearings or host events to which national EU permanent representations are invited. This support is acknowledged to enable groups to place their issues on a transnational level, build a profile for their organization, network with other likeminded organizations, and place pressure on their national government to respond to their claims (Agustín 2012, 33).

\section{MEP $_{\mathrm{S}}$, CIVIL SOCIETY, AND GENDERED MOBILIZATIONS}

One of the six MEPs recorded a connection to the Irish national feminist organization, while other female MEPs reported their attendance at events to sponsor entrepreneurial women or parliamentary ceremonies to mark International Women's Day. Female MEPs do support organizations that have a gendered dimension, including nongovernmental organizations working for the rights of older people and carers for those with disabilities and organizing hearings to support gendered issues that have stagnated at the national level or on which there is significant contest in the domestic arena. A center-left MEP sponsored a delegation representing survivors of historical institutionalized abuse and exploitation of young women in Magdalene laundries. ${ }^{22}$ These groups were invited because "they were getting nowhere with the Irish government and they wanted to have a hearing with DG Justice, they needed to get their issues on the record and it was coming up to the setting of the terms of reference on an inquiry at the national level." She continued,

You invite all of the Irish MEPs into the room to hear the testimonies of these families and women, the evidence they have and how their campaigns for justice have been frustrated at the national level, they can also connect to other similar groups in different countries, there is loads of potential there if MEPs use it wisely.

22. Sinn Féin, "MEP Lynn Boylan Accuses Irish Government of Dragging Its Feet on Violence against Women," August 1, 2014, http://www.sinnfein.ie/contents/31147 accessed (March 18, 2017). 
This strategy can be highly contentious for individual MEPs when the state is unhappy with the level of attention paid to an issue at the transnational level. The Irish state's Permanent Representation in Brussels is invited to all public events hosted by MEPs but declined initially to meet with the Magdalene laundry delegation. After some negotiations with two Irish female MEPs, the delegation relented and held a side meeting with the civil society group. These brief examples illustrate how the interface between MEPs and civil society groups can work to support campaigns on gendered interests and the role of female MEPs in supranational lobbying on women's interests.

 WOMEN?}

Opportunities from the party political environment, levels of gender and feminist awareness supported by contacts with women's organizations, and membership on equality committees are important factors explaining legislators' actions on behalf of women (Erzeel 2015). Female representatives' political agency to act for women may be contingent on such factors. However, a focus on critical actors helps us understand how female representatives use their political agency to advance women's interests. Critical actors exhibit specific attitudes and behavior: they are attitudinally strongly motivated to promote women's interests in parliament and are highly active in representing women's issues (Celis and Erzeel 2015, 30).

Domestic political culture, the form of Europeanization, and gender regime work in this case study are contextual factors that offer few supports and incentives for female MEPs to engage in a high level of actions on women's interests. Irish female MEPs also reported no specific incentives from their parties to pursue women's issues, and on the issue of reproductive rights, an area in which change may require a series of critical acts, they detailed specific disincentives to engage. Notably, even pro-choice Irish female MEPs decline to support EP proposals on abortion, arguably one of the most topical gendered issues in the contemporary Irish context. A key finding here is that party politics and party discipline limit Irish female MEPs' political agency on women's interests. In terms of feminist awareness, Irish female MEPs largely characterize the EP as a benign context for female politicians, which is partly a function of their comparative point of reference at the 
national level, where significant gender deficits in representation remain. Overall, Irish female MEPs place little emphasis on pursuing gender equality as a specific or central concern of their role.

Using the lens of gendered mobilization, this national representation of female politicians does act for women's interests in diverse ways, including "safe claims" on issues on which women are constructed as "victims" originating outside of the EU. The rights of women in masculinized occupations, including fishing and farming, and the issue of social reproduction, particularly for working mothers and carers of the disabled and elderly, also feature reinforcing gender constructs of women as workers and mothers. However, as these MEPs do not belong to the FEMM committee, these issues are often "mainstreamed" into other committee work and portfolios that have other priorities, which may increase the risk that they are sidelined. Irish female MEPs do facilitate forms of supranational lobbying in their support of domestic women's civil society and campaign groups advocating at the EU level. This is a reflection of successful topical issue-specific campaigns that have purchase for local constituents and the continued reliance of women's organizations on supranational lobbying.

This study shows the complex and contingent interaction between female legislator's attitudes and actions and the incentives and disincentives of this transnational political opportunity context in shaping female political agency. Overall, the form of political agency experienced may produce an occasional critical act for women; however, it suggests a lack of attitudinal commitment and the absence of strong feminist capacity to use this transnational context to seek significant changes in the status of women.

Pauline Cullen is a Lecturer in Sociology at Maynooth University, National University of Ireland Maynooth:Pauline.Cullen@mu.ie

\section{REFERENCES}

Abels, Gabriele. 2015. "Where Women Stand: Descriptive vs. Substantive Representation in the European Parliament since the 2014 Election." Presented to the European Conference on Gender and Politics, Uppsala, Sweden.

Abels Gabriele, and Joyce Marie Mushaben, eds. 2012. Gendering the European Union: New Approaches to Old Democratic Deficits. New York: Palgrave Macmillan.

Agustín, Lise Rolandsen. 2012. “(Re)defining Women’s Interests? Political Struggles over Women's Collective Representation in the Context of the European Parliament" European Journal of Women's Studies 19 (1): 23-40. 
Ahrens, Petra. 2016. “The Committee on Women's Rights and Gender Equality in the European Parliament: Taking Advantage of Institutional Power Play." Parliamentary Affairs 69 (4): 778-93.

Barry, Ursula, and Pauline Conroy. 2014. "Ireland in Crisis 2008-2012: Women, Austerity and Inequality." In Women and Austerity: The Economic Crisis and the Future for Gender Equality, eds. Jill Rubery and Maria Karamessini. London: Routledge, 186-206.

Beauvallet, Willy, and Sébastien Michon. 2008. "Women in the European Parliament: Effects of the Voting System, Strategies and Political Resources: The Case of the French Delegation." GSPE Working Paper 10/28/2008, Centre for European Political Sociology, University of Strasbourg. http://aei.pitt.edu/12440/1/WPBeauvalletMichon. pdf (accessed April 20, 2018).

Bowler, Shaun, and Gail McElroy. 2015. "Political Group Cohesion and 'Hurrah' Voting in the European Parliament." Journal of European Public Policy 22 (9): 1355-65.

Buckley, Fiona. 2013. "Women and Politics in Ireland: The Road to Sex Quotas." Irish Political Studies 28 (3): 341-59.

Buckley, Fiona, and Yvonne Galligan. 2013. "Politics and Gender on the Island of Ireland: The Quest for Political Agency." Irish Political Studies 28 (3): 315-21.

Buckley, Fiona, Yvonne Galligan, and Claire McGing. 2016. "Women and the Election: Assessing the Impact of Gender Quotas." In How Ireland Voted 2016: The Election That Nobody Won, eds. Michael Gallagher and Michael Marsh. Basingstoke: Palgrave Macmillan, 185-205.

Busby, Amy. 2013. "Bursting the Brussels Bubble: Using Ethnography to Explore the European Parliament as a Transnational Political Field.” Perspectives on European Politics and Society 14 (2): 203-22.

Celis, Karen, and Sarah Childs. 2012. "The Substantive Representation of Women: What to Do with Conservative Claims?" Political Studies 60 (1): 213-25.

Celis, Karen, Sarah Childs, and Johanna Kantola. 2016. "Regendering Party Politics: An Introduction." Party Politics 22 (5): 571-75.

Celis, Karen, Sarah Childs, Johanna Kantola, and Mona Lena Krook. 2014. "Constituting Women's Interests through Representative Claims." Politics \& Gender 10 (2): 149-74.

Celis, Karen, and Silvia Erzeel. 2015. "Beyond the Usual Suspects: Non-Left, Male and Non-Feminist MPs and the Substantive Representation of Women." Government and Opposition 50 (1): 45-64.

Chaney, Paul. 2012. "Critical Actors vs. Critical Mass: The Substantive Representation of Women in the Scottish Parliament." British Journal of Politics \& International Relations 14 (3): 441-57.

Childs, Sarah, and Mona Lena Krook. 2009. “Analyzing Women's Substantive Representation: From Critical Mass to Critical Actors." Government and Opposition 44 (2): $125-45$.

Cullen, Pauline. N.d. "The European Parliament as a 'Useful' Context for Feminist Activism in Ireland?" In Gendering the European Parliament, eds. Petra Aherns and Lise Rolandsen Agustín. Forthcoming.

Cullen, Pauline, and Mary Murphy. 2016. "Gendered Mobilizations against Austerity in Ireland." Gender, Work \& Organization 24 (1): 83-97.

Dahlerup, Drude. 1988. "From a Small to a Large Minority: Women in Scandinavian Politics." Scandinavian Political Studies 11 (2): 275-98.

Devitt, Camilla. 2016. "Mothers or Migrants? Labour Supply Policies in Ireland 19972007.” Social Politics 23 (2): 1-26.

Domingo, Pilar, Rebecca Holmes, Tam O’Neil, Nicola Jones, Kate Bird, Anna Larson, Elizabeth Presler-Marshall, and Craig Valters. 2015. Women's Voice and Leadership in Decision-Making: Assessing the Evidence. London: ODI. 
Elomäki, Anna. 2015. “The Economic Case for Gender Equality in the European Union: Selling Gender Equality to Decision-Makers and Neoliberalism to Women's Organizations." European Journal of Women's Studies 22 (3): 288-302.

Erzeel, Silvia. 2015. "Explaining Legislators' Actions on Behalf of Women in the Parliamentary Party Group: The Role of Attitudes, Resources, and Opportunities." Journal of Women, Politics \& Policy 36 (4): 440-63.

Fortin-Rittberger, Jessica, and Berthold Rittberger. 2014. “Do Electoral Rules Matter? Explaining National Differences in Women's Representation in the European Parliament.” European Union Politics 15 (4): 496-520.

Hobson, Barbara. 2003. "Recognition in Universal and Gender Distinctive Frames." In Recognition Struggles and Social Movements: Contested Identities, Agency and Power, ed. Barbara Hobson. Cambridge: Cambridge University Press, 64-92.

Irvine, Jill, Sabine Lang, and Celeste Montoya. n.d. "Gendered Mobilizations in an Expanding Europe." In Gendered Mobilizations and Intersectional Challenges: Contemporary Social Movements in Europe and the United States, eds. Jill Irvine, Sabine Lang, and Celeste Montoya. Lanham, MD: Rowman \& Littlefield. Forthcoming.

Jacquot, Sophie. 2015. Transformations in EU Gender Equality Policy: From Emergence to Dismantling. New York, Palgrave Macmillan.

Kantola, Johanna, and Lise Rolandsen Agustín. 2015. "European Parliament's Party Groups: Gendered Practices and Co-operation." Presented at the European Conference on Gender and Politics, Uppsala, Sweden.

- 2016. "Gendering Transnational Party Politics: The Case of European Union." Party Politics 22 (5): 641-51.

Karamessini, Maria, and Jill Rubery. 2013. Women and Austerity: The Economic Crisis and the Future for Gender Equality. Abingdon: Routledge.

Lühiste, Maarja, and Meryl Kenny. 2016. "Pathways to Power: Women’s Representation in the 2014 European Parliament Elections." European Journal of Political Research 55 (3): 626-41.

Mackay, Fiona. 2008. "Thick' Conceptions of Substantive Representation: Women, Gender and Political Institutions." Representation 44 (2): 125-39.

McElroy, Gail, and Kenneth Benoit. 2012. "Policy Positioning in the European Parliament." European Union Politics 13 (1): 150-67.

McEvoy, Caroline. 2016. "Does the Descriptive Representation of Women Matter? A Comparison of Gendered Differences in Political Attitudes between Voters and Representatives in the European Parliament." Politics \& Gender 12 (4): 754-80.

McGauran, Anne-Marie. 2005. "Plus ça change? Gender Mainstreaming of the Irish National Development Plan." Blue Paper 15, Policy Institute, Trinity College Dublin. https://www.tcd.ie/policy-institute/publications/bluepaper_15.php (accessed April 20, 2018).

Murphy Mary C., and John O'Brennan, eds. 2014. "Reflections on Forty Years of Irish Membership of the European Union." Special issue, Administration 62 (3).

Murray, Rainbow. 2015. "What Makes a Good Politician? Reassessing the Criteria Used for Political Recruitment." Politics \& Gender 11 (4): 770-76.

Mushaben, Joyce Marie. 2015. "Undermining Critical Mass: The Impact of Treaty Reforms on EP Decision-Making Culture." Presented at the European Conference on Gender and Politics, Uppsala, Sweden.

Mushaben, Joyce Marie, and Gabriele Abels. 2015. "The Lack of Gender Equality in EU Decision Making Means Citizens Are Still Suffering from a 'Double Democratic' Deficit.” http://blogs.lse.ac.uk/europpblog/2014/08/28/the-lack-of-gender-equality-in- 
eu- decision-making-means-eu-citizens-are-still-suffering-from-a-double-democraticdeficit/ (accessed April 20, 2018).

Nelsen, Brent F., and James L. Guth. 2015. Religion and the Struggle for European Union: Confessional Culture and the Limits of Integration. Washington, DC: Georgetown University Press.

Nielsen Pristed, Helene, and Lise Rolandsen Agustín. 2013. "Women, Participation and the European Parliament." In Negotiating Gender and Diversity in an Emergent European Public Sphere, eds. Birte Siim and Monika Mokre. Basingstoke: Palgrave Macmillan, $201-22$.

Quinlan, Stephen, and Martin Okolikj. 2016. “This Time It's Different ... but Not Really! The 2014 European Parliament elections in Ireland.” Irish Political Studies 31 (2): $300-314$.

Yin, Robert. 2014. Case Study Research: Design and Methods. 5th ed. Thousand Oaks, CA: Sage. 